IJLR: International Journal of Law Recontruction

Volume 5, Number 1, April 2021

DOI : http://dx.doi.org/10.26532/ijlr.v5i1.13636

\title{
THE IMPLEMENTATION OF DIPLOMATIC LEGAL PRINCIPLES: GERMAN EMBASSY STAFF VISITING ISLAMIC DEFENDERS FRONT (FPI) HEADQUARTERS CASE
}

\author{
Fradhana Putra Disantara \\ University of Jember Indonesia \\ dfradhana@gmail.com
}

\begin{abstract}
This legal research uses a conceptual approach and statue approach; by using primary and secondary legal materials. The purpose of this legal research is to describe the principles of diplomatic law and their application to the case of actions of German Embassy staff who have visited the headquarters of the Islamic Defenders Front (FPI). The results of this study indicate that diplomatic law is a system containing various principles of international law to regulate diplomatic relations between countries with universal approvement. Then, the development of diplomatic law is very progressive; marked by various conventions and codifications to create holistic norms. Furthermore, the actions of German Embassy staff visiting FPI headquarters cannot be justified by diplomatic law. This is because the potential acts of espionage by German Embassy staff also target the violation of the principle of non-intervention. Hence, on diplomatic law; violation of the principle of non-intervention creates persona non grata consequences.
\end{abstract}

Keyword: Diplomatic Law, German Embassy, Islamic Defenders Front, NonIntervention, Persona Non-Grata.

\section{A. INTRODUCTION}

In essence, the development of diplomatic law is in line with the development of international relations; as a consequence of joint efforts to maintain relations between countries as 'smoothly as possible'. ${ }^{1}$ The desire to build a holistic diplomatic legal framework is based on the reason for the protection of all technical layers of diplomatic events, particularly state agents (diplomats) who have substantial expertise in the framework of international culture and politics. ${ }^{2}$ The codification process of customary law norms is influenced by the state of political stability in the country and abroad in a country. Therefore, the fulfillment of diplomatic relations aims to 'raise difficult issues'; and is considered unsolvable, except in the presence of cooperation. ${ }^{3}$ Therefore, diplomatic law is positioned as the principles of

1 Amal Clooney and Philippa Webb, The Right to a Fair Trial in International Law, Oxford University Press, New York, 2021.

2 Albrecht Glitz and Erik Meyersson, Industrial Espionage and Productivity, American Economic Review, Vol. 110, No. 4 April, 2020. Page 1055-1103.

3 Harlan Grant Cohen and Timothy Meyer, eds., International Law as Behavior, Cambridge University Press, New York, 2021, Page 120. 
impartial mediation between sovereign States; and become a 'vehicle' for transformation for a more just and more prosperous international order for all mankind.

The development and application of diplomatic legal principles shows the desire for state, sub-state, and entities that are not universally recognized as states to have recognition in the international world. ${ }^{4}$ Then, this is driven by the essence of state diplomacy which aims to ensure that both parties are appropriate parties and become serious actors in the members of the international community. It is this mutual support that makes global politics an arena to increase the popularity of a country and increase the potential for peace in a region that is currently in 'tension'. ${ }^{5}$ The principles of diplomatic law are reflected in various universally recognized norms, doctrines, principles and concepts. The various principles of diplomatic law are crystallized in the form of conventions and codifications regarding diplomatic law; to encourage and realize diplomatic law as a 'dignified and sovereign legal system'. ${ }^{6}$

The application of diplomatic legal principles begins to become problematic when the international political infrastructure is used as a utility relationship; which involves international trade agreements as a joint project between countries. ${ }^{7}$ Not only that, the supremacy of international diplomatic law (especially on various principles recognized by international law) is considered to make it difficult to match international political preferences between the two countries Latent imperialism through the issue of economic and social development assistance carried out by a country against another country is a loophole for violating diplomatic legal principles. ${ }^{8}$ Not only that, the legal gap currently occurring is a single interpretation of a country on the norms and principles of diplomatic law. ${ }^{9}$ This is due to the nature of the meaning of diplomatic law itself which is still being debated among legal academics. ${ }^{10}$ On the other hand, a big question arises about 'whether' diplomatic law is included in international law; or 'how' the position of diplomatic law at the level of international law. Therefore, the essence of realizing the principles of diplomatic law is very much needed to continue to promote peace between countries. ${ }^{11}$ Moreover, the principles of diplomatic law are recognized as pillars of the international order as the best

4 Nicole Scicluna, Politics International Law, Oxford University Press, New York, 2021, Page 16.

5 Scicluna, Page 19.

6 Javier Solana, The Case for 'Human Diplomacy, The Hague Journal of Diplomacy , Vol. 15, No. 4 October, 2020. Page 670-80.

7 Marko Novaković, ed., Diplomatic Immunity: Evolution and Recent Country Developments, Springer Nature, Singapore, 2020, Page 27.

8 Francis A Boyle, World Politics, Human Rights, and International Law, Lanham: Rowman \& Littlefield, 2021, Page 93.

9 Boyle, Page 94.

10 Sundaresh Menon, The Rule of Law, the International Legal Order, and the Foreign Policy of Small States, Asian Journal of International Law, Vol. 10, No. 1 January, 2020. Page 5067.

11 Anna Raphael, Retroactive Diplomatic Immunity, Duke Law Journal, Vol. 69, No. 1, 2020. Page 1425-59. 
instrument to promote and protect the interests of states in relation to other States.

The application of diplomatic legal principles is being tested; 'Whether 'diplomatic law can give full respect to the state's sovereignty, or can it allow the honor to be merely a 'slogan'. The 'test' took place in Indonesia, when on 18 December 2020, German Embassy staff were found to have visited the headquarters of the Islamic Defenders Front (FPI) in Petamburan. ${ }^{12}$ This action caused controversy, considering that there are currently legal cases being experienced by FPI members. ${ }^{13}$ The German Embassy acknowledges this; on the pretext that the German Embassy staff did not take official action from the German government, however, through the Embassy staff's own initiative. ${ }^{14}$ However, the visit of the German embassy staff to the FPI headquarters raised various issues, including the overflowing issue of potential espionage carried out under the pretext of diplomats by the German Embassy. ${ }^{15}$ This issue is getting stronger, there are provisions that strictly prohibit spying in the country where he works; even the Minister of Foreign Affairs has the right to expel the diplomat. ${ }^{16}$

The legal research on the principles of diplomatic law and its application in real legal cases has been carried out three times by other researchers. The first research was carried out by Dewa Gede Sudika Mangku, Nyoman Tia Resita Dewi, I Wayan Lasmawan (2020) regarding the legal consequences of abusing diplomatic immunity rights in terms of the 1961 Vienna Convention (Case Study of Gold Smuggling Conducted by North Korean Diplomatic Officials in Bangladesh); which explained that the legal consequence of the abuse of immunity rights related to diplomatic bags / bags for Bangladesh as a receiving country is that under Bangladeshi law, North Korean diplomatic representatives can be subject to death penalty, life imprisonment and fine, but North Korean diplomatic representatives have immunity that cannot sentenced to these penalties. The second research was conducted by Devi Yusvitasari (2019) regarding the Application of Persona Non Grata Principles to Ambassadors from an International Legal Perspective (Case Study of the Persecution of Tki by the Ambassador of Saudi Arabia in Germany); which explained that the actions of the diplomatic representatives of Saudi Arabia who have carried out abuses against migrant workers are contrary to Article 41 paragraph (1) of

12 Firdiansyah, "Extra Judicial Killing Dan Cermin Polri Di Kasus Laskar FPI," cnnindonesia.com, 2020, https://www.cnnindonesia.com/nasional/20201215105638-13-582248/extra-judicialkilling-dan-cermin-polri-di-kasus-laskar-fpi.

13 Firdiansyah.

14 Danu Damarjati, "Staf Ke Markas FPI, Penjelasan Kedubes Jerman Ini Dianggap Merendahkan," news.detik.com, 2020, https://news.detik.com/berita/d-5304137/staf-kemarkas-fpi-penjelasan-kedubes-jerman-ini-dianggap-merendahkan.

15 Kukuh S. Wibowo, "Pengamat Curiga Kunjungan Staf Kedubes Jerman Ke Markas FPI Kegiatan Spionase," tempo.co, 2020, https://nasional.tempo.co/read/1416487/pengamatcuriga-kunjungan-staf-kedubes-jerman-ke-markas-fpi-kegiatan-spionase.

16 Irfan Kamil, "Staf Kedubes Jerman Yang Sambangi Markas FPI Dilarang Masuk Ke Indonesia," kompas.com, 2020, https://nasional.kompas.com/read/2020/12/29/20233871/staf-kedubes-jerman-yangsambangi-markas-fpi-dilarang-masuk-ke-indonesia?page=all. 
the 1961 Vienna Convention because they do not respect national laws and statutory regulations in the country where they are accredited. The third research was conducted by Ocone Gilbert Pasali (2017) on the Effectiveness of the 1961 Vienna Convention on Diplomatic Relations in Providing Legal Protection for Diplomats (Case Study of the Detention of Malaysian Diplomats in North Korea); which stated that the application of the 1961 Vienna Convention in the legal protection of Malaysian diplomats in North Korea was ineffective. This is evidenced by the bad faith of the North Korean government by detaining Malaysian diplomats.

The three studies above are different from the research entitled The Implementation Of Diplomatic Legal Principles: German Embassy Staff Visiting Islamic Defenders Front (FPI) Headquartes Case; because this research discusses the principles of diplomatic law, especially regarding the definition of diplomatic law, the position of diplomatic law in international law, and the development of diplomatic law from time to time. On the other hand, another difference between this study and the three previous studies lies in the orientation of the research. This study seeks to describe the application of diplomatic legal principles to the potential for espionage and violations of the principle of non-intervention in cases of visits by German embassy staff to FPI headquarters. Therefore, the researcher also argues that the consequence of this action is persona non-grata. Whereas the three previous studies, were more oriented towards different cases, explained the aspect of diplomatic immunity only, and assessed the level of effectiveness of international regulations regarding diplomatic relations.

This legal research aims to describe the principles of diplomatic law and their application to the cases of actions of German Embassy staff who have visited FPI headquarters. Thus, the researcher made a series of efforts and identifications to obtain the truth of coherence regarding the principles of diplomatic law; as well as identifying diplomatic legal concepts according to international legal experts and the position of diplomatic law at the level of international law. Not only that, the researchers describe the historical developments of diplomatic law.

\section{B. RESEARCH METHODS}

This research is legal research; The legal issues studied were the principles of diplomatic law and the application of diplomatic principles in the case of German Embassy staff visiting the headquarters of the Islamic Defenders Front. This legal research wants to use the statue approach and conceptual approach. Researchers also conducted a legal analysis of the case of German embassy staff who had visited the Islamic Defenders Front Headquarters; in order to get a conclusion about 'whether' the act can be justified by law or not. Researchers used primary legal materials including: The Charter of the United Nations of 1945, Vienna Convention on Diplomatic Relations of 1961, Vienna Convention on Consular Relations of 1963, Additional Protocol I, Geneva Conventions of 1949, Brussels Declaration of 1874, Lieber Code of 1863, Hague Regulations of 1899. Not only that, researchers also use secondary legal materials in the form of national and 
international journals, books, dissertations, proceedings, legal works; which discusses the principle of non-intervention in diplomatic law, persona non grata, the concept of diplomatic law, the history of the development of diplomatic law, and matters relating to the substance of research. Researchers made an inventory of primary and secondary legal materials in order to obtain prescriptions. ${ }^{17}$ Then, the researcher analyzed the data using a deduction pattern; so that researchers explain various principles of diplomatic law in relation to the legal problems raised, then explain legal facts then through systematic, orderly, and logical explanations. The benefits of this research are divided into two aspect; that is, theoretical and practical benefits. The theoretical benefit of this legal research is as a form of diplomatic legal scientific development. Meanwhile, the practical benefit of this legal research is that it can be used as a guideline for the government to act responsively in case of problems regarding diplomatic relations with guest countries.

\section{RESULTS AND DISCUSSION}

\section{The Principles of Diplomatic Law}

Eileen Denza stated that the 1961 Vienna Convention became the basis for an international diplomatic legal order that had codified the rules for embassy exchanges between sovereign states. ${ }^{18}$ The 1961 Convention was asked to be the main point of diplomatic law because it was known to have won in formal support and was very high in the degree of obedience of the international community. This is based on three aspects. ${ }^{19}$ First, codified legal rules in conventions have been obeyed stably and are still relevant in this modernization era. Second, reciprocity or causation as stated in the substance of the convention is very effective; so that it can be obeyed as a source of international diplomatic law. Third, the countries involved in the preparation process for diplomatic law-making in the international law commission in the Vienna convention have a common intention to find progressive solutions and solutions that are acceptable to all countries. ${ }^{20}$

Furthermore, Quincy Wright argues that diplomatic law is the art of negotiating to achieve the maximum goals of authority at the least possible cost in a political system that has the potential to cause war; ${ }^{21}$ while still relying on the principles and provisions of international law. This is based on the existence of diplomatic relations, relations between

17 Peter Mahmud Marzuki, Penelitiam Hukum, 13th ed. Kencana, Jakarta, 2017, Page 41.

18 Eileen Denza, Diplomatic Law: Commentary on the Vienna Convention on Diplomatic Relations, Oxford University Press, New York, 2016, Page 21.

19 Eileen Denza, Nationality and Diplomatic Protection, Netherlands International Law Review, Vol. 65, No. 3 October, 2018, Page 463-80.

20 Brian G. Slocum and Jarrod Wong, The Vienna Convention and the Ordinary Meaning of International Law, Yale Journal of International Law, Vol. 46, No. 2, 2021, Page 8.

21 Quincy Wright, Law in Diplomacy . Percy E. Corbett, Frederick S. Dunn, The Journal of Modern History, Vol. 32, no. 3 September, 1960, Page 277-78. 
countries will function in a stable and orderly manner. ${ }^{22}$ The outcome of diplomatic relations will imply a feeling of future security for the whole country. ${ }^{23}$ On the other hand; According to him, diplomacy is a strategic step to prevent war, with a special mission to regulate relations with the state on a continuous basis. ${ }^{24}$ Typically, diplomacy is based on respect for the principles and rules of international law and procedure. ${ }^{25}$

Then Harold Nicolson revealed that diplomatic law is a process of managing relations between independent countries which is carried out through a negotiation process by taking into account the principles of related international law. ${ }^{26} \mathrm{He}$ argued that the first principle that every country must have is the granting of diplomatic immunity. ${ }^{27}$ This has something to do with the negotiation process between sending countries and receiving countries. The event that worries Harold Nicolson is that the envoy of one of the parties was killed on arrival in the receiving country; so that no negotiations can reach a satisfactory conclusion between the two parties. ${ }^{28}$ Negotiation is the first pillar as a communication channel between state authorities designed to promote foreign policy; either an agreement or a formal adjustment. Negotiation is an important perspective considering that it is to secure the foreign policy objectives of a country without any destructive elements. ${ }^{29}$

What about diplomatic legal positions? Does diplomatic law relate to the source of international law? Yes, it is; that the source of diplomatic law relates to the source of international law. ${ }^{30}$ This is because the development of diplomatic law between sovereign countries is carried out based on the customs of international law; ${ }^{31}$ which is also one of the sources of international law contained in Article 38 of the Statute of the International Court of Justice. On the other hand, official relations between countries regulated in various provisions of diplomatic law have the same frequency and substance as the source of international law, namely providing legitimacy and validity of action for the countries involved. ${ }^{32}$ Historically, diplomatic law has encouraged countries to give recognition and respect for joint efforts to create 'the

22 Quincy Wright, Western Diplomacy Since 1945, The ANNALS of the American Academy of Political and Social Science, Vol. 336, No. 1 July, 1961, Page 144-53.

23 Julia Gray and Philip Potter, Diplomacy and the Settlement of International Trade Disputes, Journal of Conflict Resolution, Vol. 64, No. 7-8 August, 2020, Page 1358-89.

24 Novaković, Diplomatic Immunity: Evolution and Recent Country Developments, Page 81.

25 Quincy Wright, Territorial Propinquity, American Journal of International Law, Vol. 12, No. 3 July, 1918, Page 519-61.

26 Harold Nicolson, Diplomacy, Institute for the Study of Diplomacy, Washington, 1988.

27 Harold Nicolson, Diplomacy Then and Now, Foreign Affairs, Vol. 40, No. 1, 1961, Page 39.

28 William Thomas Worster, Cases and Materials on the Law of International Organizations, Routledge, New York, 2020, Page 154.

29 Stephen B. Goldberg et al., Dispute Resolution: Negotiation, Mediation, Arbitration, and Other Processes, Kluwer Law International B. V., Alphen aan den Rijn, 2020, Page 144.

30 Kriangsak Kittichaisaree, International Human Rights Law and Diplomacy, Edward Elgar Publishing, Cheltenham, 2020, Page 170.

31 C Sophia Müller, The Role of Law in Enforcing Peace Agreements: Lessons Learned from Colombia, Journal of Conflict and Security Law, Vol. 1, No. 1 January, 2021, Page 1-40

32 Müller, Page 14. 
world peace'.

The above is a moral demand taken from the essence of international law, namely lifting the equality of degrees ataa sovereign countries. ${ }^{33}$ Then, the legal mind rather than diplomatic law is to preserve the dignity of the territorial jurisdiction of a country, so that each country that becomes the sending country respects the law (with the consequence of obtaining legal protection) rather than the receiving country. ${ }^{34}$ The phenomenon is in line with the principles of professionalism and proportionality of aspects of international legal corridors that uphold the nature of official relations between countries. ${ }^{35}$ In fact, in the implementation of diplomacy, diplomats are given immunity and privileges in performing their duties and functions; ${ }^{36}$ which is also based on international customary law as well as diplomatic-related agreements between countries. It shows the role of international law sources who always give power legitimation to the facet of diplomacy of a country. ${ }^{37}$

The development of diplomatic law over time is very progressive; characterized by various convention and codification efforts to create a variety of holistic norms to provide legitimacy in a country's diplomatic actions. The development of diplomatic law began with the 1815 Congress of Vienna (The Final Act of the Congress of Vienna on Diplomatik Ranks) which prioritizes the wisdom of relevant countries through diplomatic channels to divide European powers into three classes, as well as providing an explanation of the relative status of European powers. ${ }^{38}$ The existence of the Congress of Vienna 1815 gave birth to a formal mechanism in the implementation of international diplomatic aspects and the international diplomatic ranking system; in addition to successfully removing 'the Slave Trade Act'; this is the most important, but Congress is also considering the issue of international sea navigation. ${ }^{39}$ The Congress of Vienna clearly deserves an honorable place in diplomatic history. these congresses are the pillars on which the structure of the international diplomatic system is built, and the bolts of consensus between countries are held together. This Congress established the rules of their reciprocal relationship; and describe methods of peaceful problem solving. ${ }^{40}$

33 Novaković, Diplomatic Immunity: Evolution and Recent Country Developments, Page 90.

34 Josephat Ezenwajiaku, State Territory and International Law, Routledge, New York, 2020, Page 138.

35 Worster, Cases and Materials on the Law of International Organizations, Page 134.

36 Tim Flink, The Sensationalist Discourse of Science Diplomacy: A Critical Reflection, The Hague Journal of Diplomacy, Vol. 15, No. 3 August, 2020, Page 359-70.

37 Ignacio de la Rasilla, International Law and History: Modern Interfaces, Cambridge University Press, New York, 2021, Page 211.

38 Brian E. Vick, The Congress of Vienna, Harvard University Press, Cambridge, 2014, Page 66.

39 Adam Zamoyski, Rites of Peace: The Fall of Napoleon and the Congress of Vienna, HarperCollins UK, New York, 2012, Page 87.

40 John E. Moser, Europe on the Brink, 1914: The July Crisis, Reacting Consortium Press, Chapel Hill, 2020, Page 48. 
The congress above was enhanced by the Aix-la-Chapelle Protocol of 1818; which determines the construction of diplomatic precedent. Precedent refers to priorities; higher right to honor at ceremonial or formal events; for the ambassadors in a state. Precedents will be determined by their order by presenting their certificate or messenger letter to the host authority. When the country's representatives meet, the protocol requires that certain superior orders be followed, as an illustration, the Secretary of State takes precedence over the ambassador, and doyen the diplomatic corps has priority over other mission positions. ${ }^{41}$ Harmonization is also carried out in addition to the Congress of Aix-la-Chapelle, especially related to the division of four typical classes of diplomatic officers, namely: (a) Ambassadors, Representatives, and Nuncios; (b) An Envoy, Minister or other individual recognized as a ruler; (c) the occupant of the minister, accredited to be the crowned head; (d) Charges d'affairs, accredited by curation for foreign private businesses. ${ }^{42}$

In 1927 during the League of Nations. In accordance with the resolution of the Council of Leagues of Nations has been established an expert committee to discuss the development of codification of international law, it is reported that in the subject of diplomatic law covering branches of diplomatic relations between countries should be regulated internationally. ${ }^{43}$ Furthermore, the 1928 Havana Convention discusses various fields of diplomatic relations and applies in several American states. ${ }^{44}$ Then, the 1928 Havana Convention has a limited scope; nevertheless, the draft article was drafted successfully reaching the codification stage, and resulted in a regional convention in 1928. However, the 1928 Havana Convention only applied to the four Latin American States at first. In short, the 1928 Havana Convention provides that all diplomatic officials, regardless of their category, are entitled to the same rights, prerogatives and immunities (Article 3 ) and that all diplomatic officials must be inviolable regarding person, residence (private or official. ), and their properties, such as inviolability which includes all classes of diplomatic officers, all official personnel of the diplomatic mission, members of their respective families, and official documents, files and mission correspondence (Article 14).

During the United Nations Period, various conferences were held relating to the diplomatic aspect. In 1961, the Vienna Convention on diplomatic relations by sovereign states was signed. The Vienna Convention on diplomatic relations in 1961 is an international agreement that gave birth to a comprehensive framework in terms of

41 Cohen and Meyer, International Law as Behavior, Page 29.

42 Beatrice de Graaf, Fighting Terror after Napoleon: How Europe Became Secure after 1815, Cambridge University Press, New York, 2020, Page 256.

43 Dewa Gede Sudika Mangku, Hukum Diplomatik Dan Konsuler, Lakeisha, Klaten, 2020.

44 Montell Ogdon, The Growth of Purpose in the Law of Diplomatic Immunity, American Journal of International Law, Vol. 31, No. 3 July, 1937, Page 449-65. 
diplomatic relations between countries that were already independent. ${ }^{45}$ This convention covers Vienna Convention of Diplomatic Relations, Optional Protocol Concerning acquisition of Nationality, and Optional Protocol Concerning the Compuklsary Settlement of Disputes. ${ }^{46}$ The agreement encourages the implementation of a country's diplomatic mission properly; with the privileges held by every state diplomat. The agreement can also allow diplomats to carry out their duties and functions without intimidation by the host country. This agreement is the legal basis for diplomat immunity in a host country.

The Vienna Convention of Diplomatic Relations is the cornerstone of the international legal order, which codifies the rules for embassy exchanges between sovereign states. ${ }^{47}$ Although the Vienna Convention of Diplomatic Relations contained elements of progressive development when adopted, the Convention now has nearly universal participation and represents established law. ${ }^{48}$ Vienna Convention of Diplomatic Relations discusses the draft of a number of articles that have been given by the International Law Commission on the part of the United Nations; which finally agreed upon a number of 53 articles regulating diplomatic relations. ${ }^{49}$ This Convention is a codification of the privileges and immunities of the diplomats of each country, which has a diplomatic mission and carries the rights and obligations of the state attached to itself.

Then there are Vienna Convention on Diplomatic Relation and Optional Protocols 1963. The convention aims to codify customary law on bilateral diplomatic relations between independent countries. ${ }^{50}$ On the other hand, this convention contains provisions which have become part of international law. ${ }^{51}$ The Vienna Convention on Diplomatic Relations and Optional Protocols of 1963 provides a comprehensive framework and international standards on consular relations; starting from the technical aspects, the function of consular agents, the privileges and immunity of consular agents. ${ }^{52}$ There are two optional protocols added to this Convention; that is Optional Protocol Concerning Acquisition of Nationality and Optional Protocol Concerning the Compulsary Settlemet of Disputes. The two protocols embody a general framework of minimum standards for the conduct of consular relations. In addition, the two protocols recognize the validity of other agreements, bilateral or regional, that existed before the Vienna Convention on Consular Relations (VCCR) came into effect and the conclusions of treaties that complement, expand or strengthen the

45 Vick, The Congress of Vienna, Page 301.

46 Vick, Page 303.

47 Vick, Page 307.

48 Slocum and Wong, The Vienna Convention and the Ordinary Meaning of International Law.

49 Slocum and Wong.

50 Rasilla, International Law and History: Modern Interfaces, Page 311.

51 Novaković, Diplomatic Immunity: Evolution and Recent Country Developments, Page 61.

52 Rasilla, International Law and History: Modern Interfaces, Page 313. 
provisions of the VCCR. ${ }^{53}$ This resulted in a Convention with a broad subject area, providing a wide range of tasks for consular agencies, from offering assistance and protection to citizens to promoting the development of commercial, economic, cultural and scientific relations between sending and receiving countries.

Furthermore, there was the Convention on Special Missions and Optional Protocol in 1969 which was adopted by the General Assembly of the United Nations on December 8, 1969, together with the Optional Protocol Concerning the Compulsary Settlement of Disputes. The purpose of this convention is to give legitimacy to diplomats privileges and immunities relating to special missions. ${ }^{54}$ However, the existence of this legitimacy is not to benefit the individual but to ensure but to ensure the efficient performance and special mission function of a diplomat. $^{55}$ This Convention provides that the representatives of the state on a special mission cannot be violated and cannot be arrested or detained at the point on the other hand that the receiving country must take a strategic step to ensure that diplomats receive comprehensive protection from any attack on the personality, liberty and dignity of the diplomatic state. Further, the Convention also grants immunity from administrative and civilian jurisdictions of the receiving country, with the same exceptions that apply to members of diplomatic missions. ${ }^{56}$

Furthermore, there are also Convention on the Prevention and Punishment of Crimes against Internationally Protected Person, including Diplomatic agents adopted by the General Assembly of the United Nations under resolution 3166 (XXVIII) of 14 December 1973. The Convention provides for the prevention and punishment of criminal acts directed against protected persons, including diplomatic agents. This Convention provides protection for the Head of State, the Minister of Foreign Affairs, or representatives or officers of a State or international organization; who are entitled to special protection in a foreign country. ${ }^{57}$ Thus, if someone carries out an attack in any form against a diplomatic agent of a country; then a sanction will be imposed in the form of extradition. This convention is a strategic step to maintain friendly relations and to maintain and guarantee the quality of cooperation between countries; because it contains various provisions regarding cooperation, additional provisions, the delivery of information, and the consequences that will be given to the person carrying out the attack on a diplomatic agent.

Furthermore, there is the Vienna Convention on the Representation of States in their Relations with International Organization of a Universal Character in 1975 which regulates the relations between States and international organizations between

53 Scicluna, Politics International Law, Page 93.

54 Scicluna, Page 98.

55 Raphael, Retroactive Diplomatic Immunity.

56 Nicolson, Diplomacy.

57 Clooney and Webb, The Right to a Fair Trial in International Law, Page 212. 
governments that are universal (those whose membership and responsibility are on a world scale), and with representatives of States at conferences organized by or under the aegis of that organization. This Convention establishes the scale of immunity and privileges for diplomats to maximize the permanent mission of the countries with which these international organizations are associated. ${ }^{58}$ Most international organizations of a universal nature have their headquarters, and hold most of their meetings, in Western countries.

\section{The Implementation of Diplomatic Legal Principles to the Case of German Embassy Staff Go to the Headquarters of the Islamic Defenders Front}

The actions of German embassy staff CANNOT be justified by diplomatic law. This is based on various arguments.

First. The arrival of German embassy staff to the FPI headquarters could potentially lead to espionage. Espionage is defined as the act of gathering or trying to gather information in an area controlled by an adverse party; through acts committed under false or intentional reasons. ${ }^{59}$ This definition has been stated in Article 88 Lieber Code of 1863, Article 19 Brussels Declaration of 1874, Article 29 Hague Regulations of 1899, and Article 46 Paragraph (4) Additional Protocol I. ${ }^{60}$ Regarding espionage activities, international law does not yet have a comprehensive legal umbrella to regulate it. ${ }^{61}$ Only the Lieber Code of 1863 (Article 88), the Geneva Conventions of 1949 (Article 5), and the Brussels Declaration (Article 20) did little to say about enforcement of the law against espionage.

Espionage activity is a consequence that the 'strength' of a country is often determined by their ability to gather, understand and act on information about the international system that surrounds them. ${ }^{62}$ If another country is the enemy, espionage may constitute treason, which involves helping the enemy. Espionage involves the use of appropriate abilities to supervise, monitor, capture or extract communications, data or other information. Not surprisingly, espionage is part of intelligence activities, which are also related to the analysis of diplomatic reports, newspapers, periodicals, technical publications, commercial statistics, and radio and television broadcasts. According to Phillips and Pohl, intelligence from foreign countries tends to try to build communication and coalitions by sharing across community

58 Worster, Cases and Materials on the Law of International Organizations, Page 104.

59 Asaf Lubin, The Liberty to Spy, Harvard International Law Journal, Vol. 61, No. 1, 2020, Page 185-243.

60 Gary Ross, Espionage, the First Amendment, and the Case Against Julian Assange, International Journal of Intelligence and CounterIntelligence 33, no. 4 (October 1, 2020): 747-67, https://doi.org/10.1080/08850607.2020.1716431.

61 Paul Bjerke, Mediated Spies, Nordicom Review, Vol. 37, No. s1 July, 2020. Page 115-30.

62 Peter Gill, Of Intelligence Oversight and The Challenge of Surveillance Corporatism, Intelligence and National Security, Vol. 35, No. 7 November, 2020, Page 970-89. 
organizations within the recipient country; ${ }^{63}$ to strengthen their database of information data. Typically, they communicate with parties who are not oriented towards the vision and mission aspects of the current government. ${ }^{64}$ It is not wrong that foreign intelligence that carries out espionage tends to support opposing parties in trying to get information or state secrets that can reveal the bad side of the country. ${ }^{65}$

Thus, espionage often begins with the pretext of kindness, peace, assistance, and assistance to parties who are felt to have been harmed by the actions of the government of a country; ${ }^{66}$ by doing so they hope to get state secrets relating to the weaknesses of the political, economic, defense, social and other vital aspects. ${ }^{67}$ Therefore, the pretext of 'giving condolences for the - potential - unlawful killing of six FPI members' ${ }^{\prime 68}$ and 'get a separate picture of the security situation concerned because Friday's demonstration could potentially cross the embassy grounds' ${ }^{169}$ should be watched out as a form of early espionage; or even become part of the actions of a series of espionage carried out. The embassy can be seen as a base for diplomats and spies; ${ }^{70}$ and some diplomats are basically openly recognized spies. There is nothing wrong with Bjola \& Zaiotti saying that diplomats are above the surface operating in light; whereas spies lurk beneath the surface, operating in the dark. ${ }^{71}$

In fact, there is an opinion by Kieninger which states that there is espionage that is carried out 'legally' and 'illegally'. ${ }^{72}$ "Legal" espionage means espionage carried out by the diplomats themselves. ${ }^{73}$ Then, 'illegal' espionage is the activity of 'officers' holding 'fake positions' at the local embassy. It should be understood that there are 'fake positions' in many embassies; which turned out to be filled by spies with their main task of collecting intelligence illegally by coordinating the local spying network through the form of care, protection, material giving, and so on. ${ }^{74}$ Some embassy staff are likely operating under

63 Peter J Phillips and Gabriela Pohl, Disinformation Cascades, Espionage \& CounterIntelligence, The International Journal of Intelligence, Security, and Public Affairs, Vol. 22, No. 2 October, 2020, Page 1-14.

64 John A. Gentry, Diplomatic Spying: How Useful Is It?, International Journal of Intelligence and Counter Intelligence, Vol. 0, No. 0, April 2020, Page 1-31.

65 Gentry, Page 22.

66 Phillips and Pohl, Disinformation Cascades, Espionage \& Counter-Intelligence.

67 Gill, Of Intelligence Oversight and The Challenge of Surveillance Corporatism, Page 978.

68 CNN Indonesia, Amnesty: Polisi Tembak 6 Laskar Bisa Jadi Unlawful Killing, cnnindonesia.com, 2020, https://www.cnnindonesia.com/nasional/20201207194415-12579096/amnesty-polisi-tembak-6-laskar-bisa-jadi-unlawful-killing.

69 Damarjati, Staf Ke Markas FPI, Penjelasan Kedubes Jerman Ini Dianggap Merendahkan.

70 Ross, Espionage, the First Amendment, and the Case Against Julian Assange.

71 Corneliu Bjola and Ruben Zaiotti, Digital Diplomacy and International Organisations: Autonomy, Legitimacy and Contestation, Routledge, New York, 2020, Page 121.

72 Kieninger, The Diplomacy of Detente: Cooperative Security Policies from Helmut Schmidt to George Shultz, Page 56.

73 Flink, The Sensationalist Discourse of Science Diplomacy: A Critical Reflection, Page 99.

74 Flink, Page 100. 
informal guises to hide the fact that they work for the intelligence services. ${ }^{75}$ In some cases, they may be operating in "deep guise" under false names and nationalities. Such spies are nicknamed "illegal" because they operate without any protection offered by diplomatic immunity. ${ }^{76}$ The simple difference between 'illegal' espionage and 'legal' espionage is that if caught, 'illegal' spies can be prosecuted abroad (country of origin); while 'legal' spies cannot be prosecuted, they are given protection.

In practice, these spies always echo social identity as foreign citizens; rather than an identity as the embassy official diplomat. ${ }^{78}$ It is not wrong for the pretext of 'individual initiative' to be justified by reason; when there is action from a spy or diplomat known to the intelligence of the local country. This argument is a 'secure reason' to maintain diplomatic relations for the two countries. Even so, espionage will continue to be carried out to meet the information 'needs' of these foreign countries. This is part of the 'one step back, two steps forward' strategy ${ }_{i}{ }^{79}$ which gives the understanding that a country must know the development of weaknesses of the enemy state as a form of anticipation of future wars or interests of an international political or economic nature. Thus, it is not wrong that we should be suspicious of the statement by the German Embassy; stating that visits made by German embassy staff are on behalf of the staff themselves. It is not impossible, if you look at this case, the embassy staff tried to collect information consciously - which was done fraudulently and without consent - ordered by the German government; given that guest states in particular are the most productive perpetrators of espionage and, in general, they engage in two types of espionage, each of which is defined with reference to the type of information collected, namely political espionage and economic espionage. ${ }^{80}$

Political espionage is designed to enhance the national security of the guest country by accessing information on political, social, military turmoil and sensitive issues that are under the control of the host country. ${ }^{81}$ In this case, the actions of German embassy staff tended to lead to political espionage; because they questioned the controversy over the death of FPI members. They can also carry out information gathering and analysis activities related to government, political groups,

75 Gentry, Diplomatic Spying: How Useful Is It?

76 Lubin, The Liberty to Spy

77 Kieninger, The Diplomacy of Detente: Cooperative Security Policies from Helmut Schmidt to George Shultz, Page 157.

78 Bjola and Zaiotti, Digital Diplomacy and International Organisations: Autonomy, Legitimacy and Contestation, Page 231.

79 Ross, Espionage, the First Amendment, and the Case Against Julian Assange.

80 Pablo de Orellana, Retrieving How Diplomacy Writes Subjects, Space and Time: A Methodological Contribution, European Journal of International Relations, Vol. 26, No. 2, June 2020, Page 469-94.

81 Jaseff Raziel Yauri-Miranda, Principles to Assess Accountability: A Study of Intelligence Agencies in Spain and Brazil, International Journal of Intelligence and Counter Intelligence, Vol. 0, No. 0 December 2020, Page 1-31. 
parties, military forces, movements or other associations; believed to be linked to group or government security. It is not impossible, they are trying to persuade FPI to compromise their vision. Agent Jerrman seeks to operate by leveraging trusted relationships and positions to obtain sensitive information. They may also be looking for vulnerabilities among those who handle secrets. They may be aware of flaws in their organization's security that they can exploit. Moreover, FPI has become an organization that has been the topic of conversation recently.

Formally, espionage activities are not included in diplomatic immunity. ${ }^{82}$ In fact, the pretext of Article 29 in conjunction with Article 31 Paragraph (1) Vienna Convention On Diplomatic Relations of 1961 is often used as a 'savior excuse' so that diplomats who are also spies cannot be arrested or prosecuted by the receiving country. ${ }^{83}$ Although there is no official international definition of espionage activities and different interpretations from each country towards espionage activities; ${ }^{84}$ espionage cases tend to conflict with general principles in the UN Charter, in particular the principle of non-intervention. ${ }^{85}$

Second, the actions of German Embassy staff violated the principle of non-intervention; because there is a tendency for espionage activities. Violation of this principle does not use the presumption of innocence; considering that this principle excludes all forms of intervention by foreign parties against the personality of the State or against elements of politics, economy, culture and national sovereignty. ${ }^{86}$ On the other hand, the principle of non-intervention prohibits various uses of coercive and non-coercive actions by a country (both direct and indirect, open and covert); ${ }^{87}$ within the sovereign power of another State. The coercive action is in the form of state interference by force or by dictator; or in other words force, which basically seizes the interference of a state to control the problem in question. ${ }^{88}$ Meanwhile, non-coercive action is an attempt to agitate elements of society to disobey the legal system implemented by the government; or arousing a sense of community resistance to oppose mutually agreed government policies. Thus, the interpretation of this principle is based on the local government which is disturbed by the potential for foreign interference.

82 Raphael, Retroactive Diplomatic Immunity.

83 Jan Koura, A Prominent Spy: Mehdi Ben Barka, Czechoslovak Intelligence, and Eastern Bloc Espionage in the Third World during the Cold War, Intelligence and National Security, Vol. 35, No. 7, November 2020, Page 1-22.

84 Robin M. Blake and Yolanda K. Spies, Non-Coercive Defence Diplomacy For Conflict Prevention, Scientia Militaria, Vol. 47, No. 1, January 2020, Page 1-20.

85 Darryl Li, The Spy Who Came In from the South, Cultural Anthropology, Vol. 35, No. 2, May 2020, Page 230-36.

86 Stephen Townley, Intervention's Idiosyncrasies: The Need for a New Approach to Understanding Sub-Forcible Intervention, Fordham International Law Journal, Vol. 42, No. 4, 2019, Page 1167-98.

87 Tracey A. Sowerby and Joanna Craigwood, Cultures of Diplomacy and Literary Writing in the Early Modern World, Oxford University Press,New York, 2019, Page 121.

88 Sowerby and Craigwood, Page 122. 
That principle is a "natural consequence" rather than the principle of complete sovereignty. The principle of non-intervention as a principle of diplomatic law is an effort to guarantee the ethical quality of the relations constructed into cooperation and agreements between countries. ${ }^{89}$ The philosophical basis for the application of this principle is moral and ethical respect for the territorial sovereignty of a State which is an important foundation of international relations between sovereign states. ${ }^{90}$ The principle of non-intervention is a 'mirror image' of the rights of each sovereign State to carry out its affairs without outside interference. The principle of non-intervention aims to ward off all activities that try to limit or hinder the ability of a country to carry out its functions; to achieve some of the benefits made by the intervening state. ${ }^{91}$ If there is armed intervention or any form of interference in the form of attempted threats against the state person or elements of national politics, economy and culture; then these activities will violate international law, especially diplomatic law.

The principle of non-intervention is an inseparable part of diplomatic law; ${ }^{92}$ where diplomatic law requires the political integrity of each country to be respected by other countries. In the aspect of diplomatic law, violations of the principle of non-intervention can be in the form of support for a region or region from another country to secede, any form of encouragement to overthrow the legitimate government, intervention in political activities in any form; to community organizations or political parties or certain candidates. ${ }^{93}$ The principle of non-intervention can be said to be "respect" for the principle of state sovereignty. ${ }^{94}$ This sovereignty can be said as the existence of final and absolute political authority in the political community (state). If a country has a right to sovereignty, this implies that other states have an obligation to respect that right by, among other things, refraining from intervening in its domestic affairs. ${ }^{95}$ The principle of nonintervention identifies the state's right to sovereignty as a standard in the international community and explicitly states the respect needed for it in not intervening. The principle of non-intervention as a general term

89 Kieninger, The Diplomacy of Detente: Cooperative Security Policies from Helmut Schmidt to George Shultz, Page 201.

90 Salla Turunen, Humanitarian Diplomatic Practices, The Hague Journal of Diplomacy 15, no. 4 October 15, 2020, Page 459-87,

91 Christian Lequesne, Ministries of Foreign Affairs: A Crucial Institution Revisited, The Hague Journal of Diplomacy 15, no. 1-2, March 19, 2020, Page 1-12,

92 Abdul-Rauf Mahmoud Abba and adiq Muhammad Safiyanu, The Privileges and Immunities of Diplomatic Envoys Under International Law, International Journal of Social Sciences, Vol. 4, No. 19, 2020, Page 111-24.

93 Pierre-Bruno Ruffini, Collaboration and Competition: The Twofold Logic of Science Diplomacy, The Hague Journal of Diplomacy 15, no. 3 August 5, 2020, Page.371-82,

94 Townley, Intervention's Idiosyncrasies: The Need for a New Approach to Understanding Sub-Forcible Intervention, Page 12.

95 David Bentley, The Role of the Highest Courts of the United States of America and South Africa, and the European Court of Justice in Foreign Affairs, International Affairs, Vol. 97, No. 1, January 2021, Page 237-39. 
in diplomatic law which consists of a group of normative rules, including general principles and a set of sub-principles, rules and institutions, which prohibit intervention of various types in various concrete and circumstances.

The function of the principle of non-intervention in regulating diplomatic relations can be said to protect the principle of state sovereignty. The principle of non-intervention is enshrined in Article 2 (7) of The Charter of the United Nations of 1945 (UN CharterA country can be said to be following a policy of non-intervention when it chooses not to intervene in a situation where intervention is also a possible policy. The International Court of Justice in its decision in the Nicaragua case also quoted this principle. The court also cited four General Assembly resolutions as evidence of the state's stance on the principles of non-use of force and nonintervention. According to the International Court of Justice, coercive interference by one state in the internal affairs of another state constitutes an illegal intervention. ${ }^{96}$ The court noted in the Nicaragua ruling that compulsory conditions are met, when a country loses its 'choice of political, economic, social and cultural systems, and formulation of foreign policy'. In addition, the principle of non-intervention has been endorsed by states in the Montevideo Convention on the Rights and Duties of States (1933), Additional Protocol on Non-Intervention (1936), and a more recent resolution by OAS AG / Res. 78, entitled 'Strengthening the Principles of NonIntervention and Self-Determination of Societies and Measures to Ensure Their Obedience'. ${ }^{97}$

The obligation to adhere to the principle of non-intervention is a very important element embedded in official relationships; ${ }^{98}$ considering that the development of diplomatic law between sovereign countries is carried out based on the principles of international law. ${ }^{99}$ The principle of non-intervention provides an impetus for the state to give recognition and respect for joint efforts to create world peace. ${ }^{100}$ This is a moral demand taken from the essence of international law, which is to promote equality or sovereign states. Hence, on diplomatic law; violation of the principle of non-intervention creates persona non grata consequences. ${ }^{101}$ This is because diplomacy is the main tool of international politics to expand the term of friendship and cooperation between government agencies and international organizations. ${ }^{102}$ On

96 Gray and Potter, Diplomacy and the Settlement of International Trade Disputes.

97 Turunen, Humanitarian Diplomatic Practices.

98 Bentley, The Role of the Highest Courts of the United States of America and South Africa, and the European Court of Justice in Foreign Affairs, Page 237.

99 Yolanda Kemp Spies, The Law of Diplomacy, in Global Diplomacy and International Society, Springer International Publishing, Cham, 2019), Page 101-42.

100 Christopher Darnton, Public Diplomacy and International Conflict Resolution: A Cautionary Case from Cold War South America, Foreign Policy Analysis, Vol. 16, No. 1, January 2020, Page 1-20.

101 Spies, The Law of Diplomacy, Page 125.

102 Darnton, Public Diplomacy and International Conflict Resolution: A Cautionary Case from Cold War South America, Page 14. 
the other hand, the result of diplomatic relations will imply a feeling of security in the future for the whole country; because diplomacy is a strategic step to prevent war, with a special mission to regulate relations with the state on a continuous basis. Thus, if there is a "betrayal" in the form of a violation of the principle of non-intervention; will give birth to a conflict that can target the damage to diplomatic relations and peace between the two countries. Thus, the potential for fracturing of diplomatic relations between countries; can be resolved by committing persona non grata - by the receiving country - against violations of the principle of non-intervention by "unscrupulous" guest countries.

Third. in the case of German embassy staff visiting FPI headquarters; The staff can be persona non grata-ized, considering that they have violated the principle of non-intervention. Persona non grata is a condition when a diplomat from a guest country is unwanted to return or cannot be accepted by the receiving country; ${ }^{103}$ both after being accepted and before entering into retirement from his duties. The right of each State to declare a consular persona non grata or a diplomatic agent is the cornerstone of diplomatic and consular law enforcement mechanisms. Persona non grata is an indisputable right of a recipient country and is currently enshrined in Article 9 of the 1961 Vienna Convention on Diplomatic Relations and Article 23 the 1963 Vienna Convention on Consular Relations; both of which were based on the 1932 Harvard Draft.

Persona non grata can be implemented when the individual is accredited, thereby indicating that the nominated diplomat candidate cannot be accepted by the host country and will not be accepted after the accreditation process in response to some apparent or alleged irregularity by a diplomatic agent. The term persona non grata is a "strong" term in international diplomacy; so that persona non grata is no doubt often referred to as the 'code of ethics' of international diplomacy. ${ }^{104}$ Persona non grata as a code of ethics for international diplomacy is seen as a continuous moral imperative and obligation without regard to space and time aspects; ${ }^{105}$ which creates a moral obligation to guest countries to carry out this code of ethics continuously as a form of the reflection of good faith. This is in line with Kittichaisaree's opinion; which states that even if the ethical standards of state diplomatic relations (in the form of written agreements or international conventions) are written using 'gold ink', they will still look 'pale' as long as ethical compliance and morals of state diplomacy are not recognized or implemented. ${ }^{106}$ This conception places "good faith" as a guideline for all actualization that should be carried out in carrying out diplomatic relations to achieve a high level of political legitimacy; by

103 Lequesne, Ministries of Foreign Affairs: A Crucial Institution Revisited, Page 6.

104 Ruffini, Collaboration and Competition: The Twofold Logic of Science Diplomacy, Page 9.

105 Flink, The Sensationalist Discourse of Science Diplomacy: A Critical Reflection, Page 367.

106 Kittichaisaree, International Human Rights Law and Diplomacy, Page 188. 
strengthening public confidence in compliance with codes of ethics in host countries.

By paying attention to international code of ethics and morality, a series of state diplomatic relations will be oriented towards the interests of the wider community. The benefits felt by the community will be greater and include others. These ethical and moral aspects refer to a set of values that are held firmly, shared and passed down widely (preserved), and contain cultural social values. ${ }^{107}$ Determining persona non grata as the 'code of ethics' of international diplomacy aims to achieve values of respect for the country's sovereignty; and ensuring the quality of independence as a reflection of the application of the rule of ethics in the rule of law. Determination of the status of persona non grata is due to statements by diplomats who belittle the host country, use offensive language, criticize the head of state or head of government with personal offenses, violate legal norms of the host country, violate provisions of international law, careless diplomatic behavior, interfere with political dynamics host country, and so on. ${ }^{108}$ In the event of the various actions above, it is normal for the host government to attach a letter of request to the embassy in Indonesia to summon and ask for clarification on the diplomat who violated it. ${ }^{109}$

Thus, how the code of conduct is not enforced, the trust of the international community will fade and has the potential for diplomatic apathy; ${ }_{i}^{110}$ and a tendency not to entrust everything an offending state does. Then, if the diplomat is found guilty and negligent or has committed acts beyond the authority of the Embassy; then the sending country can withdraw its diplomats. If no withdrawal occurs, the host country can ignore the presence of a diplomatic agent or issue a diplomat; until there is a termination of diplomatic relations between the two countries. Therefore, the determination of the status of persona non grata serves to save the country's honor by assembling the rays of virtue. ${ }^{111}$ The implication above is a moral consequence considering that the diplomatic representative is a symbol of bilateral relations between the two countries; who has been granted privileges and received immunity as well.

The persona non grata facet has been fully recognized in Article 9 of The Vienna Convention on Diplomatic Relations of 1961. Therefore, not every statement resulted in the expulsion of the diplomat; but if so, it must be adjusted to Article 41 Vienna Convention on Diplomatic

107 Turunen, Humanitarian Diplomatic Practices.

108 Assemgul T. Urazayeva, The Role of Public Diplomacy in Dialogue with Foreign Public, Journal of Advanced Research in Law and Economics, Vol. 11, No. 4, June 2020, Page 1433.

109 Gracia E. Siregar, Pengaturan Hukum Internasional Tentang Perlindungan Pejabat Diplomatik Di Negara Penerima, Lex et Societatis, Vol. 8, No. 2, 2020, Page 61-69.

110 Urazayeva, The Role of Public Diplomacy in Dialogue with Foreign Public, Page 1436.

111 Daniel Manulak, A Marathon, Not a Sprint: Canada and South African Apartheid, 19871990, International Journal: Canada's Journal of Global Policy Analysis, Vol. 75, No. 1, March 2020, Page 83-94. 
Relations Of 1961. In practice, formal persona non grata statements by the receiving State are rarely issued; it is usually enough to ask for the removal of the diplomat or consular post. Often diplomatic or consular agents leave or are withdrawn before official notification. In addition, in the case of German embassy staff visiting FPI headquarters, the actions of the German "diplomatic agent" were contrary to the function of the diplomatic agent; which actually only refers to actions as, among other things: representing the sending country, protecting citizens of the sending country, negotiating with the receiving country, communicating domestic conditions and developments to the receiving country, promoting friendly relations between the two countries, developing economic, cultural and scientific relations between the two countries.

\section{CONCLUSION}

At the level of international law, diplomatic law is gaining recognition as a branch of international law that 'works' in practice on the basis of customary international law; which is also one of the sources of international law as stipulated in Article 38 of the Statute of the International Court of Justice. However, the development of diplomatic law is being tested in the case of actions by German Embassy staff who visited FPI headquarters. Such action cannot be justified by diplomatic law. This is due to the possibility of espionage by the German Embassy staff; considering that espionage can be done covertly. The espionage also targeted the violation of the principle of non-intervention by German embassy staff. Hence, on diplomatic law; violation of the principle of nonintervention creates persona non grata consequences. Thus, Indonesia should conduct persona non grata on German embassy staff as the most damning form of condemnation against foreign diplomats; given that they have been protected from arrest and other forms of prosecution under diplomatic immunity. Therefore, Germany is obliged to stop the function and mission of the staff. Such actions are symbolic gestures; which shows that Indonesia is not happy with the actions of other countries or entities, as represented by the German Embassy staff.

\section{Books:}

\section{BIBLIOGRAPHY}

Adam Zamoyski, 2012, Rites of Peace: The Fall of Napoleon and the Congress of Vienna, HarperCollins UK, New York;

Amal Clooney, Philippa Webb, 2021, The Right to a Fair Trial in International Law, Oxford University Press, New York;

Beatrice de Graaf, 2020, Fighting Terror after Napoleon: How Europe Became Secure after 1815, Cambridge University Press, New York;

Brian E. Vick, 2014, The Congress of Vienna, Harvard University Press, Cambridge; 
Corneliu Bjola, Ruben Zaiotti, 2020, Digital Diplomacy and International Organisations: Autonomy, Legitimacy and Contestation, Routledge, New York;

Dewa Gede Sudika Mangku, 2020, Hukum Diplomatik dan Konsuler, Lakeisha, Klaten;

Eileen Denza, 2016, Diplomatic Law: Commentary on the Vienna Convention on Diplomatic Relations, Oxford University Press, New York;

Francis A. Boyle, 2021, World Politics, Human Rights, and International Law, Rowman \& Littlefield, Lanham;

Harlan Grant Cohen, Timothy Meyer, eds., 2021, International Law as Behavior, Cambridge University Press, New York;

Ignacio de la Rasilla, 2021, International Law and History: Modern Interfaces, Cambridge University Press, New York;

John E. Moser, 2020, Europe on the Brink, 1914: The July Crisis, Reacting Consortium Press, Chapel Hill;

Josephat Ezenwajiaku, 2020, State Territory and International Law, Routledge, New York;

Kriangsak Kittichaisaree, 2020, International Human Rights Law and Diplomacy, Edward Elgar Publishing, Cheltenham;

Marko Novaković, ed., 2020, Diplomatic Immunity: Evolution and Recent Country Developments, Springer Nature, Singapore;

Nicole Scicluna, 2021, Politics International Law, Oxford University Press, New York;

Peter Mahmud Marzuki, 2017, Penelitian Hukum. $13^{\text {th }}$ ed. Kencana, Jakarta;

Stephen B. Goldberg, Frank E.A. Sander, Nancy H. Rogers, Sarah Rudolph Cole, 2020, Dispute Resolution: Negotiation, Mediation, Arbitration, and Other Processes, Kluwer Law International B. V., Alphen aan den Rijn;

Stephan Kieninger, 2020, The Diplomacy of Détente: Cooperative Security Policies from Helmut Schmidt to George Shultz, $2^{\text {nd }}$ ed., Taylor \& Francis Limited, Milton Park;

Tracey A. Sowerby, Joanna Craigwood, 2019, Cultures of Diplomacy and Literary Writing in the Early Modern World, Oxford University Press, New York;

William Thomas Worster, 2020, Cases and Materials on the Law of International Organizations, Routledge, New York.

\section{Journals:}

Abba-Rauf Mahmoud Abba, Adiq Muhammad Safiyanu, The Privileges and Immunities of Diplomatic Envoys Under International Law, 
International Journal of Social Sciences, Volume 4, Nomor 19, 2020;

Albrecht Glitz, Erik Meyersson, Industrial Espionage and Productivity, American Economic Review, Volume 110, Nomor 4, April 2020;

Anna Raphael, Retroactive Diplomatic Immunity, Duke Law Journal, Volume 69, Nomor 1, 2020;

Asaf Lubin, The Liberty to Spy. Harvard International Law Journal, Volume 61, Nomor 1, 2020;

Assemgul T. Urazayeva, The Role of Public Diplomacy in Dialogue with Foreign Public, Journal of Advanced Research in Law and Economics, Volume 11, Nomor 4, June 2020;

Brian G. Slocum, Jarrod Wong, The Vienna Convention and the Ordinary Meaning of International Law, Yale Journal of International Law, Volume 46, Nomor 2, 2021;

C Sophia Müller, The Role of Law in Enforcing Peace Agreements: Lessons Learned from Colombia, Journal of Conflict and Security Law, Volume 1, Nomor 1, January 2021;

Christian Lequesne, Ministries of Foreign Affairs: A Crucial Institution Revisited, The Hague Journal of Diplomacy, Volume 15, Nomor 1-2, March 2020;

Christopher Darnton, Public Diplomacy and International Conflict Resolution: A Cautionary Case from Cold War South America, Foreign Policy Analysis, Volume 16, Nomor 1, January 2020;

Daniel Manulak, 'A Marathon, Not a Sprint': Canada and South African Apartheid, 1987-1990, International Journal: Canada's Journal of Global Policy Analysis, Volume 75, Nomor 1, March 2020;

Darryl Li, The Spy Who Came In from the South, Cultural Anthropology, Volume 35, Nomor 2, May 2020;

David Bentley, The Role of the Highest Courts of the United States of America and South Africa, and the European Court of Justice in Foreign Affairs, International Affairs, Vol. 97, Nomor 1, January 2021;

Eileen Denza, Nationality and Diplomatic Protection, Netherlands International Law Review, Vol. 65, No. 3 October, 2018;

Gary Ross, Espionage, the First Amendment, and the Case Against Julian Assange, International Journal of Intelligence and CounterIntelligence, Volume 33, Nomor 4, October 2020;

Gracia E. Siregar, Pengaturan Hukum Internasional Tentang Perlindungan Pejabat Diplomatik Di Negara Penerima, Lex et Societatis, Volume 8, Nomor 2, 2020;

Harold Nicolson, Diplomacy Then and Now, Foreign Affairs, Volume 40, Nomor 1, 1961; 
Harold Nicolson, Nationality and Diplomatic Protection, Netherlands International Law Review, Volume 65, Nomor 3, October 2018;

Jan Koura, A Prominent Spy: Mehdi Ben Barka, Czechoslovak Intelligence, and Eastern Bloc Espionage in the Third World during the Cold War, Intelligence and National Security, Volume 35, Nomor 7, November 2020;

Jaseff Raziel Yauri-Miranda, Principles to Assess Accountability: A Study of Intelligence Agencies in Spain and Brazil, International Journal of Intelligence and Counter Intelligence, Volume 0, Nomor 0 , December 2020;

Javier Solana, The Case for 'Human Diplomacy, The Hague Journal of Diplomacy, Volume 15, Nomor 4, October 2020;

John A. Gentry, Diplomatic Spying: How Useful Is It?, International Journal of Intelligence and Counter Intelligence, Volume 0, Nomor 0, April 2020;

Julia Gray, Philip Potter, Diplomacy and the Settlement of International Trade Disputes, Journal of Conflict Resolution, Volume 64, Nomor 7-8, August 2020;

Montell Ogdon, The Growth of Purpose in the Law of Diplomatic Immunity, American Journal of International Law, Volume 31, Nomor 3, July 1937.

Pablo de Orellana, Retrieving How Diplomacy Writes Subjects, Space and Time: A Methodological Contribution, European Journal of International Relations, Volume 26, Nomor 2, June 2020;

Paul Bjerke, Mediated Spies, Nordicom Review, Volume 37, Nomor s1, July 2020;

Peter Gill, Of Intelligence Oversight and The Challenge of Surveillance Corporatism, Intelligence and National Security, Volume 35, Nomor 7, November 2020;

Peter J Phillips, Gabriela Pohl, Disinformation Cascades, Espionage \& CounterIntelligence, The International Journal of Intelligence, Security, and Public Affairs, Volume 22, Nomor 2, October 20, 2020;

Pierre-Bruno Ruffini, Collaboration and Competition: The Twofold Logic of Science Diplomacy, The Hague Journal of Diplomacy, Volume 15, Nomor 3, August 2020;

Quincy Wright, Law in Diplomacy, Percy E. Corbett, Frederick S. Dunn, The Journal of Modern History, Volume 32, Nomor 3, September 1960;

Quincy Wright, Territorial Propinquity, American Journal of International Law, Volume 12, Nomor 3, July 1918;

Quincy Wright, Western Diplomacy Since 1945, The ANNALS of the American Academy of Political and Social Science, Volume 336, Nomor 1, July 1961; 
Robin M. Blake, Yolanda K. Spies, Non-Coercive Defence Diplomacy For Conflict Prevention, Scientia Militaria, Volume 47, Nomor 1, January 2020;

Salla Turunen, Humanitarian Diplomatic Practices, The Hague Journal of Diplomacy, Volume 15, Nomor 4, October 2020;

Stephen Townley, Intervention's Idiosyncrasies: The Need for a New Approach to Understanding Sub-Forcible Intervention, Fordham International Law Journal, Volume 42, Nomor 4, 2019;

Sundaresh Menon, The Rule of Law, the International Legal Order, and the Foreign Policy of Small States, Asian Journal of International Law, Volume 10, Nomor 1, January 2020;

Tim Flink, The Sensationalist Discourse of Science Diplomacy: A Critical Reflection, The Hague Journal of Diplomacy, Volume 15, Nomor 3. August 2020;

Yolanda Kemp. Spies, The Law of Diplomacy, In Global Diplomacy and International Society, 101-42. Cham: Springer International Publishing, 2019;

\section{Internet:}

CNN Indonesia, "Amnesty: Polisi Tembak 6 Laskar Bisa Jadi Unlawful Killing." cnnindonesia.com, 2020.

https://www.cnnindonesia.com/nasional/20201207194415-12-

579096/amnesty-polisi-tembak-6-laskar-bisa-jadi-unlawful-killing.

Danu Damarjati, "Staf Ke Markas FPI, Penjelasan Kedubes Jerman Ini Dianggap Merendahkan." news.detik.com, 2020.

https://news.detik.com/berita/d-5304137/staf-ke-markas-fpipenjelasan-kedubes-jerman-ini-dianggap-merendahkan.

Firdiansyah. "Extra Judicial Killing Dan Cermin Polri Di Kasus Laskar FPI." cnnindonesia.com, 2020.

https://www.cnnindonesia.com/nasional/20201215105638-13-

582248/extra-judicial-killing-dan-cermin-polri-di-kasus-laskar-fpi.

Irfan Kamil, "Staf Kedubes Jerman Yang Sambangi Markas FPI Dilarang Masuk Ke Indonesia." kompas.com, 2020.

https://nasional.kompas.com/read/2020/12/29/20233871/stafkedubes-jerman-yang-sambangi-markas-fpi-dilarang-masuk-keindonesia?page $=$ all.

Wibowo, Kukuh S. "Pengamat Curiga Kunjungan Staf Kedubes Jerman Ke Markas FPI Kegiatan Spionase." tempo.co, 2020. https://nasional.tempo.co/read/1416487/pengamat-curigakunjungan-staf-kedubes-jerman-ke-markas-fpi-kegiatan-spionase 
